\title{
The challenges of full participation of laity in the mission of the church
}

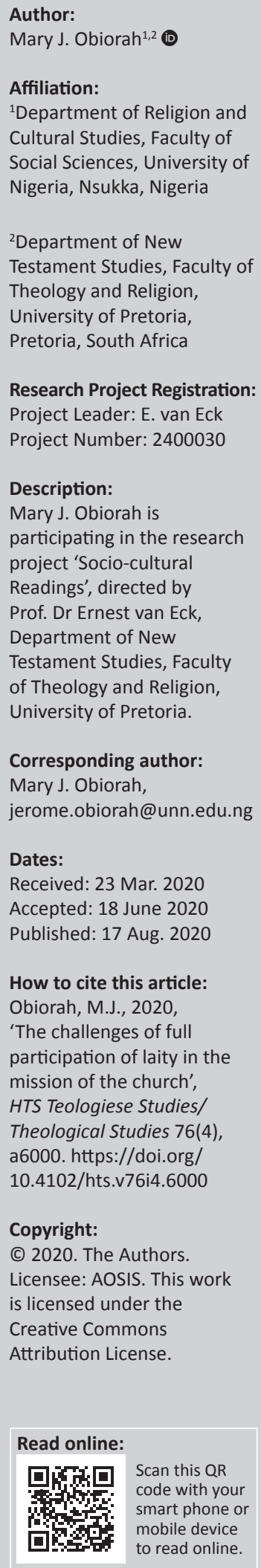

Author:

Affiliation:

${ }^{1}$ Department of Religion and Social Sciences, University of

${ }^{2}$ Department of New Testament Studies, Faculty of University of Pretoria, Research Project Registration: Project Leader: E. van Eck

\section{Description:} participating in the research Prof. Dr Ernest van Eck Department of New Testament Studies, Faculty of Theology and Religion,

Corresponding author: Mary J. Obiorah, jerome.obiorah@unn.edu.ng

Dates:

Accepted: 18 June 2020 Published: 17 Aug. 2020

How to cite this article: Obiorah, M.J., 2020

The challenges of full mission of the church', HTS Teologiese Studies/ Theological Studies 76(4), a6000. https://doi.org/ Copyright:

(c) 2020. The Authors. is licensed under the Creative Commons Attribution License.

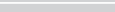

\begin{abstract}
The church shares in Christ's mission of bringing all to the knowledge of God and to salvation. All its members are called to this intrinsic mission bequeathed to the entire church. The lay faithful form the greatest number of the members and their functions are important in this mission. However, they are beset by numerous setbacks that constitute untold challenges for the church. This article, written from a sub-Saharan African and Catholic background, examines the nature of this mission as a requisite prelude to discussion on various challenges experienced by the laity in participating fully in the mission. It also recommends ways of enhancing their contributions.
\end{abstract}

Contribution: The primary contribution of this article is its specific focus on the challenges the laity encounter in carrying out their mission in the world. It is a theological study based on scriptural foundations of the laity in the church. As members, laypersons share fully in the church's received mission mandate.

Keywords: Laity; Mission; Christians; Munera Christi; Challenges.

\section{Introduction}

Reflections, strategic plans and their executions, positive attitude towards the laity and their involvement in the mission of the church are some impacts of Apostolicam Actuositatem and Lumen Gentium, chapter IV of Vatican II. Swift implementation of Apostolicam Actuositatem no. 26 followed immediately by the creation of the Pontifical Council for the Laity by Paul VI in 1967, reformed in 1976, and made a permanent Dicastery of the Roman Curia. The Synod of Bishops in 1987 on the laity was followed in 1988 by Christifideles Laici of John Paul II. Pope Francis merged the existing Pontifical Council for the Laity and the Pontifical Council for Family on 15 August 2016 and gave them a new name: the Dicastery for the Laity, Family and Life. Its creation became effective from 01 September 2016. The task of this dicastery is 'promotion of life, the apostolate of the lay faithful, the pastoral care of the family and its mission according to God's plan and for the safeguard and support of human life' (Francis 2016b:1). Similar solicitude of the church for the laity is shared by National Episcopal Conferences, Dioceses and Parishes (Wangbu 2013) through their national, provincial and diocesan laity councils.

'The Church, devoted mother, throughout the centuries, has always had care and consideration for the laity, the family and life, revealing the love of the merciful Saviour towards humanity' (Francis 2016:1). The term 'laity' (Klein 2003:415) here refers to 'all the faithful except those in Holy Orders and those who belong to a religious state approved by the Church' (Vatican II 1975a:31). Because they form the greatest part of her members, their participation in her mission is crucial for the success of the same mission entrusted to her. She nurtures and makes maximum use of their diversified gifts for the edification of the church and the world. As her baptised members they ought to participate in her mission. Many avail themselves of the formation she offers and fan their gifts into flames. Their presence in every facet of the world affords them the opportunity to penetrate more deeply those places where the mission is so much needed. The nature of their mission as Christians in the world poses untold challenges and the church readily offers assistance.

This article explores those challenges militating against full participation of the laity in the church's mission. Its premise is an understanding of this mission rooted in Christ's own mission and the status quo of the participation of the laity. These are considered necessary prelude for a meaningful discussion on the challenges they experience. Suggestions towards their enhanced mission are proffered as a contribution to the church's concern for its members. All these sequentially form the contents of the tripartite structure of this article. 


\section{Christ's mission and church's mission}

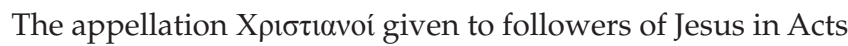
11:26 aptly depicts the common heritage of all, who, by their acceptance of baptism, profess faith in the kingdom inaugurated by Jesus. Coined from the title of 'Christ' (anointed), albeit perceived as a proper name by the Gentiles of Antioch, the term 'Christian' conveys that affinity which all followers of Jesus have with his person and mission. Central to the common vocation of Christians is utter identification with the life of Jesus, exemplified by Paul in these words: 'it is no longer I who live, but it is Christ who lives in me' (Gl 2:20).

Jesus' followers were attracted to his person and teachings which were very different from what they were accustomed to observe in other teachers of their time (Mt 7:29; Mk 1:22; Lk 4:32). His teachings were credible because the message was the messenger; he lived what he preached (Mt 9:35; Mk 6:6). His prodigies were extraordinary, surpassing those of the prophets of old. The events of his life and triumph over death convinced his followers of his divinity which formed the nucleus of the post-Paschal confession. Jesus came to lead the depraved humanity back to the Creator and he explained his mission as follows: 'I am the way, and the truth, and the life. No one comes to the Father except through me' (Jn 14:6). Jesus is the one Saviour of all, the only one, who because of his nature as God and man is able to reveal the Father and lead humanity to God (John Paul II 1991). He affirmed, 'I came that they may have life, and have it abundantly' (Jn 10:10). Firm adherence to his teaching leads one to this life and his miracles strengthened the faith of his followers, for they are a foretaste of the fullness of life in him hereafter. Jesus' mission on earth is to 'save his people from sins' (Mt 1:21), a mission that reverberates in his name, Yeshua 'salvation'.

The varied use of fulfilment formulae and copious citations of the Old Testament (OT) and New Testament writers, especially the evangelists, are meant to corroborate their claim that Jesus is the fulfilment of the Old Testament in its entirety. 'Do not think that I have come to abolish the law or the prophets; I have come not to abolish but to fulfil' (Mt 5:17). He continued the history of salvation with significant newness stated in Hebrews 1:1-2. In continuing the work of our salvation initiated in the period before his incarnation, Jesus, appropriating the words of the prophet (Is 61:1-2), reveals the novelty of his coming as Good News (Lk 4:18-19). This is the programmatic passage of the Lukan gospel. Coded in symbolic terms, the words convey the mission of Jesus, which is human salvation.

In his mission and person, Jesus embodies the threefold functions elicited from the three significant classes of persons in the Old Testament (Tangorra 2013). These are priests, prophets and kings. Ideally, a priest offers sacrifices on behalf of others and himself (cf. Heb 5:3), thereby mediating between God and human beings. A prophet [nābî'] as God's spokesperson is one who reprimands, edifies, exhorts and consoles and is convinced of the way that leads to life and teaches others to come to similar conviction so as to know God and live a life pleasing to God. A king takes care of others like a shepherd; he governs with authority for the good of others. These images in the OT, when true to the functions they depict, cooperated with the divine will of bringing human beings to the knowledge of God. They prefigured the functions of Jesus in the New Testament, the three munera Christi.

Jesus exhibited these functions to its fullness. He is not merely a priest who offers sacrifices on behalf of others; he is the priest, one who offers, and at the same time the victim, who is offered. His death on the cross is the culmination of his unique office as a priest. He is the eternal high priest whose function, prefigured in the symbolic image of Melchizedek (Gn 14:17-20; Ps 110:4; Heb 7:11-28), is timeless because those who are yet to exist share in the merit of his one sacrifice (Heb 7:24-25). Jesus is the perfect prophet, who by virtue of his divine nature is the author of the knowledge; he teaches with authority. He is the king who describes himself as 'the Good Shepherd who lays down his life for the sheep' (Jn 10:11), an imagery he draws from the OT (cf. Is 4:9-11; Ps 23; Ps 78:52; Mi 2:12-13; Jr 3:15). His Kinship is different from earthly kingships, for he came to establish the kingdom of God, contrary to the political messiah expected by his contemporaries. His is a kingdom that is first and foremost spiritual; he is the eternal king of all and at all times, and the model of all kingships.

\section{Understanding the mission of the church}

All members of the church, the body of Christ the head, participate in the threefold office of Christ by virtue of baptism, which bestows on each and every one a common dignity (Vatican II 1975a:32). In the rite for baptism, the church anoints its prospective new members with the oil of chrism and prays over them in these words (Onitsha Ecclesiastical Province 2006):

$[G]$ od the Father of our Lord Jesus Christ has freed you from sin, given you a new birth by water and the Holy Spirit, and welcomed you into his holy people. He now anoints you with chrism of salvation. As Christ was anointed Priest, Prophet, and King, so may you live always as members of his body, sharing everlasting life. (p. 15)

As a sacrament, the baptismal gestures manifest that transformation which it confers, for 'through Baptism we are freed from sin and reborn as sons of God; we become members of Christ, are incorporated into the Church and made sharers in her mission' (CCC 1994:1213).

Therefore, membership in the body of Christ through baptism as the first sacrament of initiation is the common foundation for all Christians, who in their various capacities and functions in the church become the relational concreteness of Christ the head. Those in the holy orders, consecrated life 
and the laity share in the priestly, prophetic and kingly offices of Christ according to the nature of their vocations in the church. The first are ordained to the sacred ministry, consecrated persons 'give outstanding and striking testimony that the world cannot be transfigured and offered to God without the spirit of the beatitudes' (Vatican II 1975a:31). The laity engages in temporal affairs in various ambits in the world. In other words, all Christians are called to participate in the mission of Christ entrusted to the church.

Faith and acceptance of baptism incorporate the faithful into the mystical body of Christ, making them sharers in the common priesthood of all the believers (cf. 1 Pt 2:9). The sacrament of confirmation in this initiation brings an increase and deepening of baptismal grace (CCC 1994:1303-1304; Vatican II 1975a):

$[B] y$ the sacrament of confirmation they are more perfectly bound to the Church and are endowed with special strength of the Holy Spirit, [sic] Hence they are, as true witnesses of Christ more strictly obliged to spread the faith by word and deed. (p. 11)

These sacraments that are common to all Christians and which initiate believers to the Body of Christ equip them to participate in the mission of Christ and of the church.

From the inception of his earthly ministry, Jesus explicitly called some (cf. Mk 1:16-20; Mt 4:18-22; Lk 5:1-11; Mk 2:13-17; Mt 9:9-13; Lk 5:27-32) 'to be with him, and to be sent out to proclaim the message' (Mk 3:14). Perhaps, there were others whom he called but the accounts of how they received their vocation to follow Jesus are not narrated by the Evangelists. There were also those who followed him, attracted by his person and deeds, for many who heard his words or who received favours from him became his followers. Some followed him out of personal interests and he knew the motive of each person (Jn 6:26).

When during his earthly ministry he sent out those who had been with him to preach and report back to him, he had the intention of making them participate in his mission on earth and to continue this mission after. His mission mandate confirms this: '[g]o therefore and make disciples of all nations' (Mt 28:19) and 'you will be my witnesses in Jerusalem, in all Judea and Samaria, and to the ends of the earth' (Ac 1:8). 'The proclamation and establishment of God's kingdom are the purpose of his mission' (John Paul II 1991:13). The church exists for this and to continue this mission which entails bringing salvation to all peoples. In this sense, '[s]alvation consists in believing and accepting the mystery of the Father and of his love, made manifest and freely given in Jesus through the Spirit' (John Paul II 1991:12).

The kingdom of God is characterised by its universality, for all, without exception, are called to it. The basis of missionary activity lies in the will of God, who wishes all men to be saved from damnation and come to the knowledge of the truth (Vatican II 1975b:7). It is holistic because it must touch the physical and spiritual dimensions of a human person.
The kingdom aims at transforming human relationships which must be known by its unconditional love. Furthermore, the kingdom must be a preoccupation of everyone, individuals, society and the entire world (John Paul II 1991:15). All these explain the great care taken by Jesus to ensure its continuity till its full realisation at the end of time. Similar to what Jesus did in instilling the desire for salvation in his contemporaries, those who have accepted this salvation and received the mandate to propagate it work in varied ways to bring others to the faith and to salvation. The church has therefore always understood the call to follow Christ by faith and Baptism as a call to the apostolate (Arinze 2013:11).

The intention for founding the church is for it to be at the service of the kingdom which it does in the footstep of Jesus (Vatican II 1975c:2). Foremost in its strategic plan of bringing others to the faith is by treading the path of Jesus, preaching a change of mentality, metanoia, that should conform to the dictates of the kingdom. Jesus' first proclamation was a call to conversion (Mk 1:15). Similarly, the church at the service of the kingdom preaches conversion and establishes communities of believers. It communicates the tenets of the kingdom to all it encounters. As an institution, the church is a sign of the presence of the kingdom in the world through its witness and through such activities as dialogue, human promotion, commitment to justice and peace, education and the care of the sick, and the aid to the poor and to children (John Paul II 1991:20). Jesus continues, through the church, to fulfil his mission delineated in Luke 4:18-19. Furthermore, the church, being aware of the nature of the Kingdom as God's gift, implores God for the grace on prospective believers.

The church does its mission in three circumstances where its work is needed. The first is its missio ad gentes. This is when the church endeavours to sow the seed of faith amongst (John Paul II 1991):

$[P]$ eoples, groups, socio-cultural contexts in which Christ and his gospel are not known, or which lack Christian communities sufficiently mature to be able to incarnate the faith in their own environment and proclaim it to other groups. (p. 33)

The second is missio ad intra when the church focuses primarily on the strategised pastoral care of the faithful for a sustainable Christian life in places where there is already a good ecclesial structure. The third is missio ad extra which is new evangelisation or re-evangelisation of the baptised Catholics who have lost their faith or are experiencing tepidity; the church's intention is to revive their faith. In all these three situations of its mission, the contributions of the laity are indispensable because their action within the church communities is so important that without it the apostolate of the pastors will be unable to obtain its full effect (Vatican II 1975c:10).

It is impressive to know that all the answers provided on the concept of the church's mission by the laity interviewed 
in this study are varied shades of meaning of the mission entrusted to the church. The lay persons understand Christ's mission and that the church exists to continue this mission on earth.

\section{The laity and the mission of the church in Africa}

At the time of Jesus' earthly ministry, the enormous crowd that followed him could not be compared with the limited number of his inner cycle of the 12 disciples. Many provided for his needs and those of his disciples (cf. Lk 8:1-3); they worked for the same intention of propagating the kingdom. Worth mentioning were Mary Magdalene (cf. Lk 8:2; Jn 20:11-18), Cornelius (Ac 10), Dionysius and Damaris (Ac 17: 34). Paul mentioned some whom he called 'fellow workers in the Gospel': Apollos, Aquila, Priscilla, Euodia, Syntyche, Clement, Aristarchus, Luke, Demas, Epaphras and Nympha (cf. Phlm 2:25; 4:2-3; Col 4:10-16; Rm 16: 9; Phlm 24). The number of the laity has always outnumbered those of the ministerial priesthood and of the consecrated life (Annuarium 2016). By virtue of the common priesthood of all who are baptised (cf. 1 Pt 2:9), the lay faithful share in the mission of the church, according to their various states in life; they received their mission from Christ himself.

In sub-Saharan African contexts, the lay persons interviewed in preparation for this article are aware of their participation in the mission of the church. There are, however, a few who think that this mission belongs solely to the clergy and consecrated persons. The lay faithful participate in the church's mission in various ways. They are in every sector of human life and activities (Benedict XVI 2011:131), in those places where priests and consecrated persons might not be able to penetrate. It is their special vocation 'to make the Church present and fruitful in those areas and circumstances where it is only through them that she can become the salt of the earth' (Vatican II 1975a:33). Because they are greater in number, they can reach most human beings easily and in their diversified life conditions (Benedict XVI 2005:29). Lay persons understand the situations and plight of many because they live with them in the world, intermingle daily and easily with them.

Well-informed lay faithful make incalculable impact in diverse levels of political affairs. Some of them interviewed in this study mentioned this as one of the strongest areas of their contributions to the mission of the church. They use Christian values to sanitise politics, as much as it lies in their power. Supported by priests and consecrated persons, and imbued with the tenets of their faith, the lay persons speak and act for the common good. In some places, they form Christian political leagues, creating a unified stronghold for the edification of their society.

In a world of growing disrespect for human life and that dignity bestowed on it by the Creator (Gn 1:27-28), the lay persons in medical sector, applying Catholic teachings, help to give meaning to human life. In some places in Africa, there are various associations of Catholic health workers under the auspices of local ordinary or national episcopal conferences. It is an effective means of carrying out the mission of the church. Many have been converted to the faith through the efforts of Catholic lay medical workers. Fighting against inappropriate practices that contravene both natural and divine laws in healthcare delivery system is more effective when health workers are united in a supervised Catholic association or any other Christian and non-Christian groups that share similar aspirations.

Teaching in various fields of learning has always been an efficacious means of evangelisation (Obinwa 2017:39). In the footstep of Christ and of many missionaries (Ajegbo 2016:109; Eze 2005:65), lay Catholic teachers in Africa see their vocation as a contribution to the church's mission. Knowledge of the principles of Catholic Education, universal and particular church, aids Catholic teachers in their work of evangelisation and re-evangelisation. When correctly used, they inculcate Catholic values in the recipients of their missionary activities (Anusionwu 1994:30). Voluntary Nigerian Catholic teachers in Zanzibar Island, for instance, were able to live their Catholic faith and left some Catholic imprints in this predominantly Muslim society.

The vibrant church in Africa is also blessed with many and various statutory bodies (organisations for men, women and youth) and vivacious pious associations engaged in a good number of social works and spreading of the faith. There are, for instance, the Legion of Mary, Bible societies of different kinds, Charismatic movements, Saint Anthony's Guild and many others. These associations convene regularly and have sustainable apostolates aimed at alleviating the ordeals of many less-privileged. Some members of the associations are instructors in the faith, catechists, itinerant preachers and promoters of Catholic values in their walks of life.

Similarly, various branches of Knights and their Ladies Auxiliary are all lay persons. In places where this is properly understood and there are no ulterior motives, these eminent lay faithful contribute tremendously to the mission of the church. Usually, they are educated and have adequate and ongoing formation in the Catholic faith. They are formed to defend and promote the faith. Knights and their Ladies Auxiliary in many African countries have resources to support the church's mission; they themselves participate in the same mission and have organised ways of doing it. They donate their resources for missio ad gentes or in other situations of missionary activities by training missionaries and aiding those already in mission. They financially support establishments of Catholic communities or parishes, and also sustain the existing ones.

Doctrinally well-informed lay Catholics in military and paramilitary are great treasures for the church. In spite of the challenging nature of their profession, many stand their ground in upholding Catholic values, shunning bribery of 
every category, respecting human life, serving the society selflessly and giving up their lives for the just course of their faith. Some national episcopal conferences or local ordinaries assign priests as chaplains to this group of Catholic lay missionaries. It is not rare to find them expressing their faith openly through common prayers and liturgical celebrations, and preaching verbally to their non-Catholic and nonChristian colleagues.

The growing number of religious institutes and consecrated persons in Africa witnesses an augment in the number of the laity becoming associates of these institutes. Associates voluntarily participate in the mission of the institutions by supporting them with prayers, finance, advice and sometimes engaging in their apostolate, in accordance with their state of life. Closely related to this type of missionary endeavours are instances of the laity who from their resources, like those mentioned in the gospel (cf. Lk 8:1-3), donate a greater part of their properties to the church. There are also persons who in their magnanimity have erected churches, rectories and convents for the church's mission.

The contributions of good Catholic families, where real homes and domestic churches are formed, surpass all others. Parents can create or mar a society, making it what it is through their diligence or negligence of their duties as parents (Paul II 1981:42). 'This irreplaceable role of parents in the family, the smallest unit in the society, [cannot be overemphasised] because the Christian home constitutes the first school of virtue' (Ghana Catholic Bishops 2015:n.p.). At a time like ours when there are obvious aberrations in natural and Christian values concerning families, good Catholic parents perceive their work as crucial for the church's mission (Paul II 1981:52). The church pays particular attention to families by providing adequate instructions to prospective parents and ongoing formation. Parents, on their part, continue to advance the church's concern for good Christian families and pass on the same to their posterity (Okike 2008:169). Many Catholic parents consider this a priority in their lives, despite many setbacks militating against this mission.

\section{Challenges of the mission of the laity}

It is essential to know that the laity share genuinely and naturally their challenges in participating unreservedly in the church's mission. Indeed, some adequately understand the nature of their expected contribution to the mission; they desire strongly to participate in this mission but are hindered in many ways.

Very common in their innumerable setbacks is a confirmation of Paul's insight (1 Cor 7):

$[T]$ he married man is anxious about the affairs of the world, how to please his wife ... the married woman is anxious about the affairs of the world, how to please her husband. (vv. 33-34)
Family affairs are their outstanding obstacle. Some cannot go beyond their nuclear family of spouse and children. They believe that they have a mission within their family and it is limited solely to this. Missionary activities in distant places are rare and considered as part of the vocation of priests. A call of their duties at homes disrupts some of their contributions as Christians. Their primary needs subject them to situations where they may not easily witness to their faith (Iwuamadi 2009:77).

The oldest institution of divine origin (Gn 2:18-24), marriage that forms family, is greatly besieged by perverse ideologies (Pope Francis 2016:40). Its divine origin, character and form as ordained by the Creator, one man and one woman, are questioned and altered into same-gender marriage. The natural process of procreation is abused and humans attempt to procreate through their own invented scientific means. Indeed, the social question has become a radically anthropological question (Benedict XVI 2009:1). Indissolubility of marriage carefully taught with an aetiology in Genesis 2:18-24 and corroborated in Jesus' teaching (Mt 19:1-9; Mk 10:1-12) is infringed upon, resulting in frequent divorce with its devastating repercussions (Pope Francis XVI 2016:246). Lack of sense of the sacredness of marriage affects the society in which Christians live. Families are gradually losing their status as domestic church and cradle of missionary zeal.

It is important to note that financial resources are needed in an organised work of evangelisation, and a dearth of these resources adversely affects the mission. Many people in Africa barely have enough to live on; therefore, contributing adequate resources for mission is still an unrealisable desire for many. It is common in some places in Africa to see individuals relying on external aids for their survival. Poverty, financial constraint, is the issue even when some nurture an ardent desire to participate in the church's mission. Moreover, considering the trend in the society where mostly the rich or the influential have a voice, if Christians are poverty-stricken, they may not be able to speak out in situations that require outright interjection.

If materialism is akin to avidity towards material things and their acquisition at all costs, it describes appropriately a phenomenon detected by the laity as a setback to their full participation in the mission. No one wants to engage in a non-lucrative venture from which they will gain nothing. A desire for material things has nothing in common with the propagation of the Christian faith whose aim is highly altruistic, and therefore it is not of this world. Materialistic tendency obstructs the mission and is contrary to the evangelical poverty in imitation of Jesus who became poor so that we might be rich (2 Cor 8:9).

A lack of formal education, that is, inability to read and write, debars many lay persons who are willing and available for the mission of the church for accomplishing their desires. 
There is a limit to what illiteracy can do, in spite of good will, piety and generosity. Interaction with some classes of individuals in the society becomes impossible. The situation results in a lack of facilitators of faith sharing and good witnesses of the community.

'Many are not adequately instructed in the faith' (Ghana Catholic Bishops 2015) and its repercussions are almost palpable, particularly in 'neo-pagan trend' manifested in various forms of syncretism (Ifeanyi 2017:88). The vacuum generated by inadequate instructions in the faith, or lack of knowledge of Catholic teaching, is unrestrainedly filled with practices of Traditional Religion, which are inconsonance with Christian belief. One who is not conversant with the Christian faith and praxis cannot be its herald, for 'we need knowledge and truth, because without these we cannot stand firm, we cannot move forward' (Pope Francis 2013a:24). For the laity to participate in their mission of enlivening the world, they need adequate catechesis. Without this they cannot courageously face the challenges they encounter from others, answer their questions and be a light to them.

Closely related to the facts discussed above is the lack of adequate formation of the laity towards mission (Pope Francis 2013:102). Many of them want to be involved in various aspects of the church's mission, particularly missio ad gentes, but there is no programme for this where they can live and work. They attribute this to the lack of interest by the clergy and consecrated persons. Some of them live their faith in their daily lives and make contributions for the mission. They believe that if they are instructed and co-opted, they can move beyond their immediate environment in proclaiming the faith.

Some practices of African culture are incongruous with Christian orthodoxy and orthopraxy. Some of these practices from necromancers and revival of forgotten superstitions have untold influence on the laity who, because of inadequate instructions on the faith, have not yet extricated themselves from them. Living a Christian life with identity crisis breeds syncretism, a form of infidelity, and the adherents of this mixture cannot propagate any of the two religions.

For varied reasons that often defy classification, some priests and consecrated persons, who ought to understand and recognise the dignity and contributions of the laity, are indifferent to their position in the church. They are not involved in making decisions in the church (Pope Francis 2013:102), especially where it concerns them, the common good of parish or diocese. If the primary ministers of the church are insensitive to the real situation of the laity, there is a block in spreading the gospel. The expected encouragement from them seems not forthcoming, and consequently the efforts of the laity around them are dampened, if they are not involved in evangelisation. The mission suffers because whatever the number of priests and consecrated persons in a given place, they cannot fill the part of the laity.
Like Paul, who experienced both internal and external oppositions in his mission (2 Cor 11:26), and in fulfilment of Jesus' words that internal division is inevitable in authentic discipleship (Mt 10:36), some lay faithful are hindered by fellow Catholics and non-Catholics or non-Christians. Catholics who lack the zeal obstruct others; non-Catholics and non-Christians perceive the efforts of zealous laity as overstepping the boundaries. It entails courage and fortitude to live and proclaim one's faith in a subtly hostile environment. It is more challenging to be a Catholic in a predominantly non-Christian place where religious freedom is not officially forbidden, but there is silent persecution in practice. This is the case of the laity living amongst fanatical Muslims in some parts of Africa. Official state documents remain tacit about religious freedom, but many who openly profess their belief are eliminated and the government does nothing or purports to be concerned about the victims of such unofficial religious violence. When there is oppression or determined plan by other religions to suppress and malign the Christians, they find it difficult to fully participate in the mission.

The increasing use of information and communications technology (ICT) facilitates communication, particularly in evangelisation (Inaku 2016:96), and renders the world a global village where many obtain the same information at the same time. Some contents can be beneficial when they are geared towards a vision of the person and the common good that reflects truly universal values and tenets (Benedict XVI 2009:73). Others, conversely, erode individual cultural values and lead to self-alienation. Christianity, which has fertile terrains in many parts of Africa (Paul II 1995:42), is greatly diluted because of the influence of other world cultures conveyed through ICT. This has adverse impact on orthodoxy and orthopraxy of the faith in a culture that could have naturally enhanced this faith. Affected lay persons have very little to offer for the mission because they have no natural basis offered by sound cultural values.

Some lay persons can persevere in their faith when faced by scandals of church leaders; unfortunately, others are discouraged, grow lukewarm to the extent of suffering loss of their faith. Participating in the mission of the church in the midst of clerical scandals poses tremendous challenge to the laity. The bishop of Bruges, Roger Vangheluwe, resigned in April 2010 after admitting that he had sexually abused a boy for years when he was a priest and after being made a bishop (BBC 2010:1). Bernard Preynat (75 years old), received a 5-year sentence after admitting that he had assaulted boys over a 20-year period, a scandal that embroiled a top cardinal (Breenden 2020:1). Many victims of such abuses have left the church and discouraged others with their stories and attitude towards its mission.

\section{Towards enhanced participation of the laity in the mission}

Some dioceses are engaged in the doctrinal and theological formation of the laity with organised formation programmes, theological schools, awarding certificates and diplomas in 
theology (Benedict XVI 2009). These efforts should be intensified, with missiology and orientation on mission duly incorporated in the programme, to equip the laity for the church's mission (Omeayo 2015:429).

Early missionaries achieved so much through formal education of the laity. The church in Africa must not relent in its effort to collaborate with states in offering formal education to all. It is laudable where some parishes organise adult education in their parochial schools. This is highly recommended; they can make use of volunteers for the affordability of this education for those with limited resources.

The church has always cared for families, recognising them as an indispensable organ of evangelisation (Anyawu 2015:230). Dioceses, parishes and religious institutes should bring the documents of the church on families to the grassroots level. These should be essential materials in their ongoing formation, which must be taken seriously by all competent authorities.

Parish and pastoral councils in many parts of Africa incorporate the laity and involve them in their decisionmaking. This should be encouraged in places where it does not currently exist (McGraw 2019). Knowing the laity's essential roles in the mission of the church, religious leaders ought to bring them closer with respect and concern for their welfares.

In places where there is commitment to ecumenism and inter-religious dialogue (Paul II 1995:65), peace thrives and healthy co-existence is facilitated. This fosters freedom to practise one's religion and collaborative efforts with other Christians in inculcating Christian values in the society (Kanuba 2016:128). Leaders should make it their priority and carry the laity along in the course of ecumenism and inter-religious dialogue.

The lay faithful believe and propose assiduous prayers for missionary zeal; these are highly needed in our time that is pervaded by materialism, individualism and selfishness, which are incompatible with Christian tenets and missionary spirit.

More than ever, the formation of youth is so much required in our time, mainly where youth no longer give the hope of being the future of the society and the church. Existing youth formation programmes in many parts of Africa should be vivified and new establishments should be made.

\section{Conclusion}

Conscious of the varieties of charisms united by their common source, the Holy Spirit, and that these form a glaring beautiful mosaic edifying the Body of Christ, the church is ever concerned about all its members who bear these divine gifts. The church's dynamic feature inspired and guided by the same spirit helps it grow steadily in its understanding of each person's dignity and vocation. This explains the church many endeavours in the form of teaching, synods and publications on various aspects of its life and mission. The church progresses in its knowledge of the mission bequeathed to it by Christ by sharing in his own mission of redemption, for its existence coincides with this mission.

The lay members enjoy the church's loving concern for all her children for she constantly plans on how to carry everyone along and helps them realise their vocations and fructify their individual gifts. Through the efforts of the church, the lay faithful have come to appreciate their dignity and vocation. They share in various ways, according to their understanding and capacities, in its mission. Through them the church is able to permeate all sectors of human life because they live and work in places which only they can adequately evangelise. Being aware of their indispensable role in bringing the gospel to the ends of the earth, the church nurtures them, paying particular attention to the cradle, the human family, where all should first receive the fundamental instructions on the common vocation of Christians.

As their various gifts and life conditions are, so are their hindrances in giving themselves unreservedly to the work of evangelisation, particularly in reaching out to persons and societies far from their vicinities. Natural family engagements, lack of adequate preparations, expected support from leaders, poverty manifesting in varied ways and perverting effects of globalisation that lead to self-alienation are some of the many challenges that stare the laity in the face. The church can assist by intensifying its maternal roles of encouraging, equipping spiritually, morally and physically, so as to accomplish its mission through all its members.

\section{Acknowledgements}

The author thanks the Sisters of the Immaculate Heart of Mary, Mother of Christ in Kenya and Ghana, Pontifical Missionary Societies, and Anglophone Africa for their contributions to this research article.

\section{Competing interests}

The author declares that she has no financial or personal relationships that may have inappropriately influenced her in writing this research article.

\section{Author's contributions}

M.J.O. is the sole author of this research article.

\section{Ethical considerations}

This article followed all ethical standards for research without direct contact with human or animal subjects.

\section{Funding information}

This research received no specific grant from any funding agency in the public, commercial or not-for-profit sectors. 


\section{Data availability statement}

Data sharing is not applicable to this article as no new data were created or analysed in this study.

\section{Disclaimer}

The views and opinions expressed in this article are those of the author and do not necessarily reflect the official policy or position of any affiliated agency of the author.

\section{References}

Ajegbo, M., 2016, 'Archbishop Charles Heerey's contribution to education and politics in Nigeria', in M.N. Eze (ed.), Christian faith and mission in East Nigeria, pp. 109-127, Totan, Owerri.

Annuarium Statisticum Ecclesiae of 2016, viewed 28 February 2019, from https:// press.vatican.va/content/salastampa/it/bollettino/pubblico/2018/06/13/ 0440/00957.html.

Anusionwu, V.O., 1994, The role of the laity in missionary activities of the Church in Igboland of Nigeria: A historical and pastoral approach, Pontificia Universitas Urbaniana, Rome.

Anyanwu, S.O., 2015, 'The role of the Church in rehabilitating the family today', in L.E. Ijezie, S. Audu, A.I. Acha (eds.), The family and the new evangelization, pp. 230-238, CATHAN Publication, Port Harcourt.

Arinze, F., 2013, The layperson's distinctive role, Ignatius Press, San Francisco, CA.

Benedict XVI, 2005, Encyclical letter, God is love (Deus caritas est): On Christian love, Libreria Editrice Vaticana, Vatican City.

Benedict XVI, 2009, Encyclical letter, Charity in truth (Caritas in veritate): On integral human development, Libreria Editrice Vaticana, Vatican City.

Benedict XVI, 2011, Post-Synodal apostolic exhortation, Africae uunus, on the Church in Africa in service of reconciliation, justice and peace, Libreria Editrice Vaticana, Vatican City.

British Broadcasting Corporation (BBC), 2010, Catholic Church sex abuse scandals around the world, viewed 14 September 2018, from https://www.bbc.com/ news/10407559.

Breenden, A., 2020, Ex-Priest in France is convicted of abusing dozens of scouts, viewed 18 March 2020, from https://www.nytimes.com/2020/03/16/world/ europe/bernard-preynat-france-abuse.html.

Eze, M.N., 2005, Archbishop Charles Heerey and the history of the Church in Nigeria 1880-1967, St. Paul's, Mumbai.

Ifeanyi, V., 2017, 'Practical Atheism: A problem of faith in Nigeria', Ministerium 3(1), 88-109.

Inaku, K.E., 2016, 'Nurturing faith in the new media age', The Oracle 3(4), 83-101.

Iwuamadi, L., 2009, 'The challenges of African Christian in the light of Mark 10:29', African Journal of Contextual Theology 1(2009), 75-82.

John Paul II, 1981, Familiaris consortio, Libreria Editrice Vaticana, Vatican City.
John Paul II, 1991, Encyclical letter redemptoris missio: On the permanent validity of the church's missionary mandate, Libreria Editrice Vaticana, Vatican City.

John Paul II, 1995, Post-Synodal Apostolic exhortation (Ecclesia in Africa): On the Church in Africa and its evangelising mission towards the year 2000, Libreria Editrice Vaticana, Vatican City.

Kanuba, A.C., 2016, 'Relevance of ecumenical education in the promotion of peacefu co-existence in Nigeria', The Nigerian Journal of Theology 30(1), 113-128.

Klein, E., 2003, A comprehensive etymological dictionary of the English language, Elsevier, London.

McGraw, M.D., 2019, The critical role of the laity in the church today, viewed 05 March 2019, from https://stjoan.org/the-critical-role-of-the-laity-in-the-church-today/.

Obinwa, I.C., 2017, 'Make disciples of all nations: Reading Matthew 28:16-20 in the context of Christianisation and Islamisation strategies in Nigeria', Ministerium $3(1), 34-50$

Okike, B.O., 2008, 'The role of the laity in dialogue', Koinonia 4(1), 169-170.

Omeayo, A.S., 2015, 'Catechesis and evangelization in the religious formation of the laity in Nigeria', in L.E. ljezie, S. Audu, A.I. Acha (eds.), The family and the new evangelization, pp. 429-446, CATHAN Publication, Port Harcourt.

Onitsha Ecclesiastical Province, 2006, Usoro emume sakramenti, Donachuks Publishers, Onitsha.

Pope Francis, 2013a, Encyclical letter, the light of faith (Lumen fidei), Libreria Editrice Vaticana, Vatican City.

Pope Francis, 2013b, Apostolic exhortation, evangelii gaudium, on the proclamation of the gospel in today's world, Libreria Editrice Vaticana, Vatican City.

Pope Francis, 2016a, Apostolic letter motu proprio: Instituting the dicastery for the laity, the family and life, viewed 12 February 2019, from http://w2.vatican.va/ content/francesco/en/motu proprio/documents/papa-francesco-motuproprio_20160815 sedula-mater.html.

Pope Francis, 2016b, Statutes of the new dicastery for the laity, family and life, Libreria Editrice Vaticana, Vatican City.

Pope Francis, 2016c, Post-Synodal apostolic exhortation on love in the family (Amoris Laetitia), Libreria Editrice Vaticana, Vatican City.

Tangorra, P.F., 2013, 'Jesus Christ: Priest, prophet, and king', Homiletic and Pastoral Review, viewed 19 January 2019, from https://www.hprweb.com/2013/10/jesuschrist-priest-prophet-and-king/.

The Catholic Bishops' Conference of Nigeria, 2009, Salt of the earth and light of the world: Manual of the laity, Catholic Secretariat of Nigeria, Abuja.

The Ghana Catholic Bishops' Conference, 2015, 'The laity in the context of the new evangelisation', in Communiqué of the Plenary Assembly 6th-14th November, 2015, viewed 09 January 2019, from http://accracatholic.org/category news-hedlines/.

The Roman Catholic Church, 1994, The Catechism of the Catholic Church (CCC), Paulines Publications Africa, Nairobi.

Vatican II, 1975a, Dogmatic constitution on the church: Lumen gentium, in A. Flannery (ed.), Costello Publishing, New York, NY

Vatican II, 1975b, Decree on the church's missionary activity: Ad Gentes Divinitus, in A. Flannery (ed.), Costello Publishing, New York, NY.

Vatican II, 1975c, Decree on the apostolate of lay people: Apostolicam actuositatem, in A. Flannery (ed.), Costello Publishing, New York, NY.

Wangbu, J.K., 2013, Laity in Nigeria, Post Vatican Il experience, SNAAP, Enugu. 